\title{
Die oor-en-weer beroep van predikante tussen die Nederduitse Gereformeerde Kerk en die Nederduitsch Hervormde Kerk van Afrika: 1862-1917
}

\begin{tabular}{|c|c|}
\hline \multicolumn{2}{|l|}{$\begin{array}{l}\text { Author: } \\
\text { Flip du Toit }{ }^{1}\end{array}$} \\
\hline \multicolumn{2}{|c|}{$\begin{array}{l}\text { History and Church Polity, } \\
\text { Faculty of Theology, } \\
\text { University of Pretoria, } \\
\text { South Africa }\end{array}$} \\
\hline \multicolumn{2}{|c|}{$\begin{array}{l}\text { Dr Flip du Toit is a research } \\
\text { associate in the Department } \\
\text { of Church History and Church } \\
\text { Polity, Faculty of Theology, } \\
\text { University of Pretoria, } \\
\text { Pretoria, South Africa. }\end{array}$} \\
\hline \multicolumn{2}{|c|}{$\begin{array}{l}\text { Correspondence to: } \\
\text { Flip du Toit }\end{array}$} \\
\hline \multicolumn{2}{|c|}{$\begin{array}{l}\text { Email: } \\
\text { flip.dutoit@up.ac.za }\end{array}$} \\
\hline \multicolumn{2}{|c|}{$\begin{array}{l}\text { Postal address: } \\
\text { PO Box 12101, Hatfield } \\
\text { Pretoria, South Africa }\end{array}$} \\
\hline \multicolumn{2}{|c|}{$\begin{array}{l}\text { Dates: } \\
\text { Received: } 29 \text { May } 2015 \\
\text { Accepted: } 10 \text { July } 2015 \\
\text { Published: } 30 \text { Sept. } 2015\end{array}$} \\
\hline \multicolumn{2}{|c|}{$\begin{array}{l}\text { How to cite this article: } \\
\text { Du Toit, F., 2015, 'Die oor-en- } \\
\text { weer beroep van predikante } \\
\text { tussen die Nederduitse } \\
\text { Gereformeerde Kerk en die } \\
\text { Nederduitsch Hervormde } \\
\text { Kerk van Afrika: 1862-1917', } \\
\text { HTS Teologiese Studies/ } \\
\text { Theological Studies 71(3), } \\
\text { Art. \#3060, } 8 \text { pages. http:// } \\
\text { dx.doi.org/10.4102/hts. } \\
\text { v71i3.3060 }\end{array}$} \\
\hline \multicolumn{2}{|c|}{$\begin{array}{l}\text { Copyright: } \\
\text { (C) 2015. The Authors. } \\
\text { Licensee: AOSIS } \\
\text { OpenJournals. This work is } \\
\text { licensed under the Creative } \\
\text { Commons Attribution } \\
\text { License. }\end{array}$} \\
\hline \multicolumn{2}{|l|}{ Read online: } \\
\hline 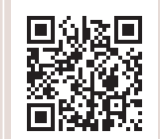 & $\begin{array}{l}\text { Scan this QR } \\
\text { code with your } \\
\text { smart phone or } \\
\text { mobile device } \\
\text { to read online. }\end{array}$ \\
\hline
\end{tabular}

The ongoing appointment of ministers between the Dutch Reformed Church and the Netherdutch Reformed Church of Africa: 1862-1917. This article highlights the situation prior to the establishment of the theological training of the Netherdutch Reformed Church of Africa (NDRCA). The training of ministers of the Dutch Reformed Church (DRC) started in 1859 with the establishment of the Theological Seminary at Stellenbosch. Since 1862 three churches operated in the then Transvaal (South African Republic). Many ministers of the DRC were called to serve in the NDRCA. The most notable were the Rev D.P. Ackerman and the Rev H.S. Bosman. They were called before the origin of the united church (of the NDRCA and the DRC) that existed between 1885 and 1892. After the split in 1892, they (as well as many others) continued as ministers in the DRC. The first lecturer of the NDRCA was called in 1917 also a minister that was previously from the DRC. The calling of his successor sparked a major row. The NDRCA congregation of Pretoria called another minister from the DRC - the Rev H.D. van Broekhuizen. This eventually led to a special meeting of the General Assembly of the NDRCA in 1917 where his calling was eventually approved.

\section{Inleiding}

Dit is 'n voorreg om mee te werk aan die huldiging van Christo van der Merwe. Hy is inderdaad 'n persoon wat as predikant van die Nederduitsch Hervormde Kerk van Afrika (NHKA) met gemak binne die Nederduitse Gereformeerde Kerk (NGK) kontak gemaak en beweeg het. As kerkhistorikus was dit dus voor die hand liggend om te dink aan daardie predikante wat so vryelik tussen die twee kerke beweeg het totdat die NHKA se eie teologiese opleiding in 1917 met die beroep van dr. J.H.J.A. Greyvenstein as eerste dosent 'n aanvang geneem het.

Die wisselwerking van predikante het destyds geskied teen die agtergrond van een kerk wat reeds opleiding plaaslik kon bied (die Teologiese Seminarium wat in 1859 deur die NGK te Stellenbosch begin is). Dit was 'n oplossing vir diegene wat as predikant opgelei wou word en nie die geleentheid gehad het om oorsee te kon gaan studeer nie.

Ten einde enigsins ' $n$ greep op die gebeure te kan kry, is dit noodsaaklik om kortliks die kerklike toneel in die ou Zuid-Afrikaansche Republiek (ZAR - ook geografies bekend as Transvaal) te skets. Sonder om die ontstaansgeskiedenis van die drie kerke te behandel, word daar gewerk met die realiteit dat daar sedert 1862 drie kerke onder die Afrikaner-gelowiges in die ZAR was: die NGK wat steeds sterk bande met die Kaapse NGK gehandhaaf het, die NHKA (die staatskerk van die ZAR) asook die Gereformeerde Kerk (GK).

Gedurende die periode 1885-1892 het twee van hierdie kerke (NGK en NHKA) verenig om die Nederduitsch Hervormde of Gereformeerde Kerk van de ZAR te vorm (kortweg ook bekend as die Verenigde Kerk of Dubbel Gereformeerde Kerk).

Die geskiedenis van hierdie vereniging en die predikante se rol daarin word nie bespreek nie. Dit kan elders volledig nagegaan word: Du Toit (1979:70-78), Engelbrecht (1953:281-301), Keet (1942:100-135) en Scholtz (1960:1-80).

Na 1892 het die NHKA weer op sy eie voort bestaan en die NGK het aangegaan, egter met die behoud van die dubbele naambeskrywing: Nederduitsch Hervormde of Gereformeerde Kerk van de ZAR. Dit is later verander na Nederduitsch Hervormde of Gereformeerde Kerk van ZuidAfrika (nog later 'van Suid Afrika') om uiteindelik in 1957 die naam te dra van die NG Kerk van Transvaal. Wanneer daar dan in hierdie artikel bloot na die NGK verwys word, is dit die NGK soos in Transvaal daar uitgesien het. 
Ter wille van die onderskeid word daar agtereenvolgens gelet op die wisselwerking in die volgende periodes: die periode voor 1885, tussen 1885 en 1892, na 1892 en dan na 1910.

\section{Die periode 1862-1885}

Ds. D.P. Ackerman voltooi sy studie te Stellenbosch en word aan die einde van 1872 gelegitimeer (Anoniem 1934:228). Hy en prop. S.J. du Toit besoek die Transvaalse gemeentes op aandrang van die Kweekskool-professore nadat 'n versoek daartoe ontvang is. Hulle besoek verskeie gemeentes en preek daar, insluitend NHKA gemeentes. Ackerman word beroep na, en uiteindelik op 09 Januarie 1875 bevestig as leraar van die Hervormde gemeente Wakkerstroom (Du Toit 1979:48-49). In hierdie gemeente het hy, ook deur die naamsveranderinge heen, gearbei totdat hy 1916 oorlede is.

Ds. J.C. de Vries het vir 'n kort tydjie as predikant van die NHKA gedien. Hy was aanvanklik vir 3 jaar hulpprediker te Sutherland, toe vir 3 jaar leraar van Dutoitspan (Kimberley). In 1876 word hy die Hervormde predikant van die gemeente Zeerust maar aanvaar reeds in 1884 'n beroep na die NG gemeente Laingsburg. Hy is dus die eerste predikant wat weer vanuit die NHKA na die NGK beroep is (Anoniem 1934:233). Hy was die predikant wat in die uiteindelike vereniging van die NGK en die NHK in 1885 'n rol gespeel het (Engelbrecht 1953:253). Hy word verkwalik omdat hy die goedkeuring van die Vereniging aanbeveel het 'bij acclamatie zonder discussie' (Engelbrecht 1953:291).

Naas Ackerman was die ander vername figuur in hierdie periode ongetwyfeld ds. H.S. (Manus) Bosman. Hy is gedoop te Victoria-Wes en word as kind groot in Potchefstroom met ds. Van der Hoff as sy predikant. Hy vertrek dan saam met ds. Andrew Murray, wat die Transvaal in 1862 deurreis het, om sy skoolloopbaan asook sy teologiese opleiding in die Kaap en Stellenbosch te voltooi (Du Toit 1979:12-46). Hy studeer verder in Europa en word aan die einde van 1875 gelegitimeer. Net hierna word hy eenparig na die Hervormde gemeente Pretoria beroep. Hy aanvaar en word op 15 Julie 1876 deur die konsulent, ds. Dirk van der Hoff, bevestig. Buiten Van der Hoff was die enigste ander leraars wat aan die handoplegging deelgeneem het die twee oudstudente van die Seminarium op Stellenbosch en bevestigde leraars in die NHKA, D.P. Ackerman van Wakkerstroom en J.C. de Vries van Zeerust (Du Toit 1979:46-55; Engelbrecht 1953:265).

Die situasie in Pretoria-gemeente was beslis nie ' $n$ maklike een vir die jong Bosman nie. Na die spanninge wat deur ds. Begeman in die gemeente veroorsaak is en nadat hy in Junie 1872 met die aanvaarding van sy emeritaat afskeid geneem het, was daar vele faksies binne die gemeente. Verskeie beroepe is uitgebring, sonder enige sukses - onder andere ook op S.J. du Toit. Daar word beswaar aangeteken teen sy beroep. Etlike maande later gee die Algemene Kommissie goedkeuring en na die lang gesloer bedank hy die beroep (Du Toit 1979:48-50). Volgens S.P. Engelbrecht was prop. S.J. du Toit so verstandig om die beroep na Pretoria te bedank (Engelbrecht 1953:265). Gedurende hierdie periode is dr. J.J. Kotze van Richmond ook na die gemeente Pretoria beroep, maar ook hy het bedank (Engelbrecht 1953:264).

Nadat die gemeente dus 4 jaar lank vakant was, is ds. Bosman bevestig. Dit was voorwaar geen maklike keuse vir enige van die drie jong leraars om 'n beroep na die NHKA te aanvaar nie. In Bosman se geval het baie hom trouens sterk afgeraai om die beroep te aanvaar. Een sterk rede vir hierdie raad was die feit dat die NHKA van teologiese liberalisme beskuldig is (vgl. Du Toit 1979:51). Die NGK in Transvaal het sterk standpunt ingeneem teen die beroeping van NG proponente na die NHKA. Op die sinode van 1873 (Sesde Algemene Kerkvergadering) is die volgende pertinent besluit (Engelbrecht 1953; Gerdener 1930:354):

De Vergadering is van gevoelen, dat geen predikant van de Nederduitsch Gereformeerde Kerk, die de waarheid lief heeft, den kansel beklimmen kan voor een der Hervormde leeraren in de Republiek, daar hij daardoor getuigenis zou afleggen tegen de Gereformeerde Kerk, en voor de Hervormde Kerk, en nog minder een beroep in de Kerk kan aannemen zonder veel schade te doen aan de zaak der waarheid in dit land, en zouden, wat zeer wenschelijk is, een of meer leeraren onzer Kerk dit land doorreizen en eenvoudig het Evangelie verkondigen, dan zullen onder Gods zegen zielen bekeerd worden, en de zaak der Kerk naar wensch bevorderd worden. (bl. 236)

Die gevoel was selfs so erg dat die Natalse NG Kerk, wat besluit het om afgevaardigdes te stuur om di. Ackerman en Bosman se bevestiging by te woon, na 'n besoek deur ds. H.L. Neethling (van Utrecht) by hulle sinodesitting, die besluit herroep en nietig verklaar het (Engelbrecht 1953:247-248).

Daar kan sekerlik baie vrae gevra word oor die redes vir hierdie besluit van die NGK se vergadering (sinode) in 1873. Een van die redes wat beslis in die agtergrond 'n rol gespeel het, was die feit dat ds. Thomas Francois Burgers (voorheen die NG predikant van Hanover) in 1872 die president van die ZAR geword het. Hoewel hy natuurlik nie beroep is as president (!) nie, het die NHKA wel 'n bepaalde rol gespeel om hom in die ZAR as president verkies te kry. Burgers was ' $n$ afgesette predikant vanweë sy liberale sieninge in die teologie. Hy het egter sy saak teen sy skorsing in die Kaapse Hoërhof gewen. Voor sy aanstelling as president het hy die Transvaal verskeie kere besoek. Hoewel sy besoek deur die NGK geïgnoreer is, was dit nie die geval met die NHKA nie - op daardie stadium ook amptelik die staatskerk (Engelbrecht 1953:244, 257, 270-272; Scholtz 1956:233, 238-242, 245).

By die volgende (sewende) Algemene Kerkvergadering van die NGK in die Transvaal, gehou vanaf 11 Oktober 1875, is dieselfde voorstel rakende die aanvaarding van beroepe van NGK predikante na die NHKA bespreek. Ds. J.P. Jooste van Potchefstroom wou 'n verandering in die besluit aanbring deur die NHKA as susterskerk te erken. Hy herhaal dat die besluit van 1873 'n onchristelike oordeel vel oor predikante wat na die NHKA gaan en dat daar baie predikante in 
die Kaap is wat hierdie besluit betreur. Die vergadering oordeel egter anders en handhaaf 1873 se besluit (Gerdener 1930:357-359).

Dit is eers by die agtste Algemene Kerkvergadering (gehou vanaf 04 Junie 1877) dat die situasie ingrypend verander het. Drie beskrywingspunte wat voor die vergadering dien, toon aan dat hier ernstig aandag gegee is aan 'n nuwe verhouding met die NHKA. Die eerste beskrywingspunt, van die kerkraad van Marico, vra dat oorweging geskenk moet word aan die moontlikheid om die Kaapse NGK te vra vir 'n kommissie ten einde toenadering tussen die twee kerke (NHKA en NGK) te bewerkstellig. Die tweede beskrywingspunt, van die kerkraad van Soutpansberg, versoek dat die Algemene Vergadering besluit

dat het haar eene smart is, dat jonge leeraren der Ned. Geref. kerk, in de Kaapkolonie, met voorbijzien harer besluiten en verloochening harer regten, de Herv. kerk versterken tegen ons, en geven desnoods hiervan schriftelijk kennis aan de Synode der Ned. Geref. kerk in de Kaapkolonie. (Gerdener 1930:364).

Laastens is daar die beskrywingspunt van ouderling Kleynhans wat vra dat 1873 se besluit gewysig, en beter nog, nietig verklaar sal word (Gerdener 1930:364).

Tydens die bespreking van bogenoemde sake het twee ouderlinge voorgestel dat die tyd nou aangebreek het om die besluit van 1873 terug te trek en ook nietig te verklaar. Ds. J.P. Jooste, voorsitter (predikant van Potchefstroom), gee die stoel af aan ouderling Viljoen ten einde self aan die bespreking te kan deelneem. Hy reken hierdie voorstel van die twee ouderlinge is die vernaamste saak waaraan die vergadering aandag moet gee. Die NGK is nie in Transvaal net daar terwille van ' $n$ klein groepie nie, maar vir die ganse Afrikaanse bevolking. As verdere belangrike redes vir die noodsaak vir verandering van die standpunt behandel hy die tradisionele besware wat rakende teologiese liberalisme teen die NHKA gehou is: Die NHKA is nie meer 'ontaard' nie, hulle het Belydenisskrifte aangeneem, hulle het 'n goeie ondertekeningsformulier vir predikante en hulle het regsinnige predikante beroep. Hy reken dat die besluit van 1873 'n oordeel vel oor 'onze regtzinnige broeders in de Hervormde Kerk' (Gerdener 1930:365). Sou die besluit van 1873 nietig verklaar word, is daar 'n kragtige hefboom om samewerking veral op die gebied van die opvoeding daar te stel. Na heftige bespreking waarin ander afgevaardigdes sterk teen hierdie voorstel praat, is dit wel by wyse van meerderheidstem aanvaar (Gerdener 1930:364-366).

Benewens hierdie reaksie en besluite van die NGK moet ook onthou word dat by die NHKA bepaalde sake 'n rol gespeel het. So verklaar die Hervormde kerkhistorikus, prof. S.P. Engelbrecht, later dat die ZAR se val (na die Jameson Inval) onder andere veroorsaak is deur'die optrede van die Nederduitse Gereformeerde predikante in Transvaal. Hulle het as kinders van hulle tyd niks gevoel vir die nasionale strewe van die Transvaal van daardie dae nie' (Engelbrecht 1953:269). Op dieselfde trant reken hy dat buiten die fortuinsoekers van Pelgrimsrust ook die leiers van die Transvaalse Ned. Geref. Kerk, soos beliggaam in ds. F. Lion Cachet, die onafhanklikheid van Transvaal in die wiele gery het (Engelbrecht 1953:270).

Wat ook al die onderskeie kerke se menings was, die feit is dat voortgegaan is om die tekort aan predikante in Transvaal aan te vul met leraars wat uit die Kaapkolonie beroep is. So kom ook ds. Charl Wynand du Toit na Transvaal. Hy het 'n interessante geskiedenis gehad. Hy was sedert 1869 predikant van Hanover Vrye Gemeente. Hy word in 1874 leraar te Pearston en daarna in 1875 van die afgeskeie gemeente Kruisvallei. In 1883 volg hy ds. Van der Hoff op as leraar van die NHKA gemeente Potchefstroom waar hy leraar bly tot met die aanvaarding van sy emeritaat in 1918 (Anoniem 1934:235; Engelbrecht 1953:280).

\section{Die periode 1885-1892}

Met die eenwording van die NHKA en NGK in 1885 met die dubbeldoor naam Nederduitsche Hervormde of Gereformeerde Kerk van de Zuid-Afrikaansche Republiek was die weg gebaan vir die vrye beroep van die proponente en predikante wat in Stellenbosch opgelei is. Tydens hierdie periode word die volgende leraars dan ook beroep en bevestig:

Ds. P.W. Ennis 1886 te Ermelo (Anoniem 1934:236); ds. J.N. Martins in 1888 te Johannesburg (Anoniem 1934:246); ds. A.M. de Villiers in 1888 te Hartebeestfontein (Anoniem 1934:232); ds. M.L. Fick in 1889 te Potchefstroom (Anoniem 1934:237); ds. W.F. Knobel in 1891 te Bloemhof (Anoniem 1934:241); ds. D.J. Kriel in 1889 te Ventersdorp (Anoniem 1934:241); ds. C.J. Snyman in 1891 te Makwassie (Anoniem 1934:254); ds. J.W.G. Strasheim in 1890 te Klerksdorp (Anoniem 1934:255) en ds. D.J. Viljoen in 1890 te Waterberg (Anoniem 1934:260).

Hierdie stroom proponente wat uit die geledere van die NGK gekom het, is heeltemal verstaanbaar aangesien Stellenbosch se Kweekskool op daardie stadium die enigste opleiding vir predikante verskaf het.

\section{Die periode na 1892}

Nadat die twee kerke na die Trichardtsfontein uitspraak weer in twee verdeel het, het die NHKA hulle naam net so behou of dan wel die ou naam weer gebruik. Die NG Kerk het voortgegaan om te bestaan onder die naam Nederduitsche Hervormde of Gereformeerde Kerk van de ZAR (en so voortbestaan met kleiner aanpassings totdat dit in 1957 die NG Kerk van Transvaal geword het).

\section{Predikante uit die Verenigde Kerk wat voortaan by die NHKA sou aansluit as leraars}

Die bekendste predikant was sekerlik ds. C.W. du Toit wat aanbly as die predikant van die NHKA gemeente Potchefstroom. Hy het ook 'n belangrike rol gespeel in die werksaamhede van die Prokurasie Kommissie wat hulle vir die teruggawe van eiendomme aan die NHKA beywer het (Engelbrecht 1953:337-340). Nadat ds. P.W. Ennis aanvanklik 
as leraar van Ermelo (NGK) aanbly, word hy in 1905 die leraar van die Hervormde gemeente Klerksdorp (Engelbrecht 1953:357).

Sonder om hier 'n ander kategorie te skep, kan ook verwys word na ds. A. Murray wat in 1899 as die predikant van die Hervormde gemeente Rustenburg beroep en bevestig word. Hy was die seun van John Murray, gebore op 21 Februarie 1852. Na sy legitimasie in 1876 was hy 'n jaar lank die hulpprediker in Richmond. Hy word predikant in Amersfoort (1878) en toe in Jacobsdal (1881) (Anoniem 1934:247). As die konsulent van die gemeente Pretoria was hy later aktief by die beroep en bevestiging van ds. Herman van Broekhuizen betrokke.

\section{Predikante vanuit die Verenigde Kerk wat aanbly by die Kerk (dus NG gemeentes bedien)}

Di. D.P. Ackerman (Wakkerstroom) en H.S. Bosman (Pretoria) is sekerlik die bekendste leraars wat aanvanklik as NHKA leraars bevestig is, meegewerk het aan die totstandkoming van die Verenigde Kerk en toe die NGK weer afsonderlik bestaan, aangebly het as leraars.

Diegene wat na 1892 as leraars van die NGK aangebly het, was talryk (vergelyk diegene beroep tussen 1885 en 1892) met die uitsondering natuurlik van ds. P.W. Ennis wat aanvanklik aanbly, maar in 1905 na die NHKA gemeente Klerksdorp gaan.

Dan is daar ook ds. H.J.L. du Toit wat reeds voor die bestaan van die Verenigde Kerk in Potchefstroom (1882) bevestig is. Hy word in 1887 die leraar van die Verenigde Kerk Lichtenburg en word daarna in 1904 die predikant van Richmond (Anoniem 1934:235).

\section{Die veranderende situasie na 1910 in die NHKA}

Die NHKA het reeds na 1902 erns gemaak met teologiese opleiding. Hiervoor is prof. dr. P.J. Muller aanvanklik gebruik en hy het privaat twee teologiese studente opgelei. Daar was ' $n$ behoefte om met teologiese opleiding te begin en ' $n$ kuratorium is in die lewe geroep. Die eie opleiding sou egter eers 'n paar jaar later gestalte kry (Engelbrecht 1953:367-368).

Dr J.H.J.A. Greyvenstein is in 1917 as die eerste teologiese dosent vir die NHKA beroep. Hy het 'n interessante geskiedenis gehad. Afkomstig uit die distrik Barkly-Oos is hy opgelei te Stellenbosch, maar hy onderbreek sy studie om as 'n Kaapse rebel tydens die Anglo-Boereoorlog (SA Oorlog) van 1899-1902 op te tree. Na voltooiing van sy studie te Stellenbosch het hy oorsee verder gaan studeer. Daar het hy in noue aanraking met onder andere dr. H.C.M. Fourie gekom, en hy het ook met die invloedryke ouderling A.D.W. Wolmarans van die NHKA, wat tydens sy besoek aan Europa in 1910 daarop uit was om 'n dosent vir die NHKA se teologiese opleiding te werf, kontak gehad. $\mathrm{Na}$ voltooiing van sy doktorsgraad in die Nuwe Testament help hy aanvanklik in die Maitland gedeelte van Kaapstad Gemeente (Rex 1968:21-24). Hy word in 1912 predikant van die NGK Sutherland (Anoniem 1934:237). In 1914 word hy beroep na die NHKA Pretoria wat op daardie stadium 2 jaar lank vakant was na die bedanking van C.L. Ruysch van Dugteren (wat in 'n leerstryd met die NHKA gewikkel was). Tydens sy bediening te Pretoria tree hy in die huwelik met Ida Antonia Ruysch van Dugteren, die suster van die vorige leraar. Die Kuratorium van die NHKA beroep hom eenparig as die eerste voltydse dosent na die Teologiese Fakulteit aan die Universiteit van Pretoria. Hier het hy tot en met sy aftrede in 1945 werksaam gebly. Hy was algemeen bemind en bekend as Vader Greyvenstein (Rex 1968:21-24).

By die kerkraadsvergadering waar die Akte van Demissie aan dr. Greyvenstein oorhandig is (02 April 1917), sou daar direk daarna ' $n$ interessante en heftige stryd binne die NHKA begin. Dit het gehandel rondom die beroep wat die kerkraad uitgebring het op ds. H.D. van Broekhuizen, vroeër ' $n$ hulpprediker van Pretoria (1898), daarna predikant van Kuilsrivier (1903) en toe van Pretoria (1906) (Anoniem 1934:256).

Hierdie beroep en die stryd wat daarop gevolg het, dien in 'n sekere sin as hoogtepunt en afsluiting van die periode waarin NGK predikante beroep is. Aangesien dit ten nouste saamhang met die totstandkoming van die eie teologiese opleiding, is dit gepas om hieraan volledig aandag te gee.

Herman van Broekhuizen was 'n kleurryke figuur. Buiten vir die feit dat hy as Stellenbosser Suid-Afrika in 1896 op die rugbyveld teen die Britse Leeus verteenwoordig het, was 'n belangrike faktor in sy lewe die feit dat hy met Elsie Eloff, kleindogter van pres. S.J.P. Kruger, getroud was. Sy was 'n lewendige en aktiewe kultuur- en politieke stryder wat onder meer vanaf 1916 tot 1930 Transvaal se voorsitter van die Vroue Nasionale Party was.

In 1898 word Van Broekhuizen die hulpprediker van ds. H.S. Bosman in die NG gemeente Pretoria (waar ds. Bosman sedert 1876 gearbei het). Saam met pres. Kruger verlaat hy die hoofstad en vergesel hom tydens sy ballingskap na en in Europa. In 1903 word hy predikant te Kuilsrivier (naby Kaapstad) en in 1907 word hy die medeleraar van die nou reeds gesiene ds. H.S. Bosman in die NG gemeente Pretoria (Du Toit 1982:200-202).

Van Broekhuizen het tydens die Rebellie van 1914 'n belangrike rol gespeel: as vriend van genl. C.F. Beyers wat pas as Kommandant-Generaal van die SA Weermag bedank het, vergesel hy hom te velde as sy sekretaris, gee hom later oor aan die regering, word gevonnis en is in die tronk die selmaat van ds. H.C.M. Fourie van die NHKA (gemeente Erasmus (Bronkhorstspruit) - voorheen as Witfontein deel van Pretoria-gemeente). Van Broekhuizen bedank as predikant van die NG gemeente Pretoria vanweë sy deelname aan die Rebellie. Tydens sy tronkverblyf skryf hy 
'n sterk bewoorde brief aan ds. Bosman, sy eertydse kollega. Hy skryf onder andere:

Lijden voor uw volk, Weleerw. Heer, is bij U een onbekend iets. Grootpraten, heerlik klinkende zinnen - zeker en gewis - maar daden, Eerw. Heer, daden, dat is wat Uw volk van U verwachtte! Maar helaas, die daden bleven uit. (Du Toit 1982:203)

Na sy vrylating in Mei 1916 was daar 'n versoek dat hy weer in die NG gemeente Pretoria preek. Die regering het dit egter geweier aangesien dit volgens hulle sou neerkom op 'n verbreking van sy vrylatingsvoorwaardes, naamlik om nie in die openbaar op te tree nie (Du Toit 1982:205-206). Ds. Van Broekhuizen het in Pretoria bly woon. Hy is in hierdie werklose periode finansieel deur oud-gemeentelede ondersteun.

Die spanninge wat sedert 1914 rondom ds. Van Broekhuizen se deelname aan die Rebellie binne die NG gemeente Pretoria geheers het, het in 1917 na die NHKA gemeente Pretoria oorgewaai. Tydens dieselfde vergadering waarop demissie aan dr. Greyvenstein verleen is, het die kerkraad 'n nuwe leraar beroep - ds. H.D. van Broekhuizen. Hierdie beroepsvergadering het met 'n lang en heftige bespreking gepaard gegaan. Uiteindelik is ds. Van Broekhuizen met nege stemme teenoor sewe (wat op ds. S. Vermooten uitgebring is) beroep. Die gevoel in die kerkraad ten gunste van ds. Van Broekhuizen was egter baie sterker as wat die stemverdeling aantoon aangesien vier afwesige lede ds. Van Broekhuizen se beroep ook gesteun het. Hulle het dit vooraf per brief aangedui dog kon dit uiteraard nie op die vergadering as ' $n$ wettige stem geld nie (NHKA 1914-1919 [2.4.1917:195-201]).

Met hierdie beroeping van 'n NG predikant het die kerkraad 'n subtiele waarskuwing van die amptelike orgaan, De Hervormer, verontagsaam. In die uitgawe van 15 Maart 1917 is gewys op die tekort aan predikante in die NHKA, dog word daar terselfdertyd gewaarsku om nie predikante uit ander kerke in Suid-Afrika te beroep nie alvorens die name van sodanige predikante nie vooraf, ooreenkomstig Artikel 57, aan die Kommissie van die Algemene Kerkvergadering, vir goedkeuring voorgelê is nie (De Hervormer 15.3.1917:7-8).

Aangesien die Kerkraad van Pretoria nie vooraf toestemming gevra het nie, het die beroep van ds. Van Broekhuizen 'n hewige stryd tussen die kerkraad en die Kommissie van die Algemene Kerkvergadering ontketen. Dit het begin toe die Kommissie van die Algemene Kerkvergadering (ook genoem die Algemene Kommissie) op 18 April 1917 weier om ds. Van Broekhuizen se beroep goed te keur (NHKA 1917b:272-274).

'n Verontwaardigde kerkraad het op 28 April 1917 vir 'n buitengewone vergadering byeengekom. Uit die bespreking blyk dat die skriba van die Algemene Kommissie wederregtelik vir die skriba van die kerkraad opdrag gegee het om nie die beroepsbrief te stuur nie. Die kerkraad kon sy verontwaardiging oor die optrede van die Algemene Kommissie nie verberg nie. In 'n lang brief aan die Algemene Kommissie blyk hierdie gebelgdheid baie duidelik.

In die brief motiveer die kerkraad hul optrede. In Artikel 57 (a) en (b) word omskrywe welke proponente in die NHKA toegelaat word, maar daar word ook bygevoeg dat die Algemene Kommissie bevoeg is om uitsonderings hierop toe te laat. Die kerkraad is veral gebelgd omdat die Algemene Kommissie geen redes vir hulle optrede verstrek het nie. Daar is bloot gesê: Dit word verbied. Breedvoerig word dan aangetoon waarom die verontwaardiging so groot is: Toe die NHKA in 1914 net 12 diensdoenende predikante vir sy 31 gemeentes gehad het, is die beroep wat toe op ds. Van Broekhuizen uitgebring is, goedgekeur. Waar daar nou in werklikheid net agt diensdoenende predikante is (die drie predikante wat reeds diep in die sestig is, buite rekening gelaat) is die verbittering van die kerkraad te verstane. Vooruitsigte op 'n spoedige groei in die getal predikante in die NHKA het die kerkraad ook nie - slegs prop. S.P. Engelbrecht sou binnekort sy studie voltooi.

Waar die brief ingelui is met die opmerking dat die handelswyse van die Algemene Kommissie die gemeente nader aan mekaar gebring het - selfs sommige van diegene wat teen ds. Van Broekhuizen se beroep gekant was, het van sienswyse verander - word daar met 'n versoek afgesluit, naamlik dat 'n buitengewone Algemene Kerkvergadering byeengeroep word indien die Algemene Kommissie in sy standpunt sou volhard (NHKA 1914-1919 [1917:209-219]).

Die Algemene Kerkvergadering het uiteindelik eers op 20 November 1917 vir drie dae lank byeengekom - sewe maande nadat die kerkraad dit aangevra het. As gevolg van hierdie vertragingstaktiek van die Algemene Kommissie het die uiteindelike konfrontasie met die kerkraad al hewiger geword. Boonop het die simpatie met ds. Van Broekhuizen se geval eerder toegeneem as andersom.

Voordat die Algemene Kerkvergadering dus byeengekom het, was daar ook ander pogings om die spanning op te los.

Die Algemene Kommissie het besluit om op 25 Mei 1917 'n konferensie met Pretoria se kerkraad te hou. Hier is ooreengekom dat die beroep van ds. Van Broekhuizen kan deurgaan indien hy aan twee bepalings van die Kerkwet voldoen: Hy moet vooraf sy attestaat by die gemeente inlewer asook hom laat eksamineer (Artikels 2 en 24c van die Kerkwet) (NHKA 1914-1919 [28.4, 1917:221]).

Ds. Van Broekhuizen lewer hierop sy attestaat in en verklaar hom bereid om geëksamineer te word. Trouens, hy verklaar dat hy nog altyd simpatiek teenoor die NHKA was, want hy is immers in Nederland in die Hervormde Kerk gedoop. Die skriba van die kerkraad het dus reeds op 29 Mei 1917 aan ds. Jac van Belkum, skriba van die Algemene Kommissie, kennis gegee dat ds. Van Broekhuizen met die twee voorwaardes 
instem. Selfs na 'n opvolgskrywe was daar nietemin geen reaksie nie (NHKA 1914-1919 [6.7. 1917:231-233]).

Die Algemene Kommissie het heelwat later gereageer. Hulle het besluit om tog 'n Algemene Kerkvergadering byeen te roep (aanvanklik vir 30 Oktober 1917). Hier moes dan uitsluitsel gegee word oor die interpretasie van Artikel 57 van die Kerkwet (NHKA 1917:277-281 [B 1/2, 20.6]; De Hervormer, 15.7.1917:10-11).

Die kerkraad se geduld het opgeraak. Op 'n kerkraadsvergadering van 06 Julie 1917 is die aangeleentheid deeglik bespreek en ook op drastiese optrede besluit. In die bespreking wys ds. A Murray (Rustenburg en konsulent) daarop dat die optrede van die Algemene Kommissie verregaande is. Ds. Van Broekhuizen is vroeër reeds twee keer na 'n NHKA gemeente (Zeerust en Pretoria) beroep sonder dat daar enige beswaar was. Ouderling A.D.W. Wolmarans ('n senator en jare lank een van die leidende figure binne die NHKA asook in die Transvaalse politieke lewe) wys op die willekeurige handelinge van die Algemene Kommissie - waarvan hy self reeds jare lank lid was. Hy stip die enigste twee moontlikhede aan: Daar word gewag vir die Algemene Kerkvergadering en dus toegegee aan die willekeurige optrede van die Algemene Kommissie, òf daar word 'n kommissie benoem om die beroepsbrief aan ds. Van Broekhuizen te oorhandig.

Aangesien die kerkraad met reg ontevrede was, besluit hulle om die beroepsbrief te oorhandig. ' $n$ Verdere motivering vir hierdie houding was dat hulle ds. Van Broekhuizen nou in beskerming moes neem. Nadat die kerkraad die versekering van die konsulent, ds. A. Murray gekry het dat hy bereid is om ds. Van Broekhuizen te bevestig indien hy sou aanvaar, is ' $n$ lang voorstel aanvaar wat na die Algemene Kommissie deurgestuur is.

In hierdie voorstel word die geskiedkundige verloop van die gebeure vanaf 25 Mei 1917 geteken. Daar word gewys op die versekerings wat ds. L.E. Brandt, die voorsitter van die Algemene Kommissie, in die drie-uur lange samesprekings met die kerkraad gegee het: dat ds. Van Broekhuizen slegs aan daardie twee voorwaardes moes voldoen, dat hulle die sake sou bespoedig, dat die oorspronklike beroepsbrief nog geldig was en dat die kerkraad die gemeente kon meedeel dat hulle op 'n bevredigende oplossing kon vertrou. Nadat ds. Van Broekhuizen sy instemming met die twee voorwaardes betuig het, is daar egter nie spoedig deur die Algemene Kommissie gereageer nie. Vanweë hierdie toedrag van sake spreek die kerkraad sy diepe teleurstelling oor die Algemene Kommissie se houding uit. Hulle is verder nie geneë om die belange van die gemeente langer aan die willekeur van die Algemene Kommissie op te offer deur die beroep vir nog 'n verdere vier maande uit te stel nie. Die beroepsbrief sal gevolglik oorhandig word en ' $n$ afskrif van die besluit aan die Algemene Kommissie gestuur word:

Ten slotte besluit de Kerksraad, de A(lgemene) K(ommissie) te doen opmerken dat de Kerkeraad door een 'Verklaring' van ds. Van Broekhuizen te vragen geenzins bedoelt uit te drukken, van mening te zijn, dat de A. K. recht had zulks te eisen van een beroepen predikant uit een zuster-Kerkgenootschap; maar dat de Kerkeraad zulks alleen heeft gedaan met het oog op de toestand en de belangen der Gemeente ... En aangezien Ds. Van Broekhuizen zich de vernedering heeft laten welgevallen door zijn attestatie in te dien en bij deze Gemeente (welke vernedering nog nooit aan enige beroepen predikant in de Herv. Kerk is aangedaan...) en Ds. Van Broekhuizen zich dus door de eis van de A.K., op verzoek van de Kerkeraad van zijn eigen kerk heeft losgemaakt mag de Kerkeraad, wil hij zichzelf eren, nu niet anders doen kan dan W.Eerw. Ds. v. Broekhuizen in bescherming (te) nemen tegenover het gedrag van de A.K. (NHKA 1914-1919:235)

Hierdie voorstel is, met uitsondering van ouderling A.D.W. Wolmarans, algemeen aanvaar. (Ouderling Wolmarans het om verstaanbare redes versoek om buite stemming te bly). Verder is besluit om 'n brosjure uit te gee waarin die kerkraad sy standpunt deeglik toelig. Ook die gemeente sou volledig ingelig word en indien ds. Van Broekhuizen die beroep aanvaar, sou die bevestiging op 05 Augustus 1917 plaasvind. Ten slotte besluit die kerkraad om 'n kommissie aan te stel om die korrektheid van alle stukke met die oog op ds. Van Broekhuizen se moontlike bevestiging na te gaan omdat dit eintlik, volgens Kerkwet, deur die voorsitter en skriba van die Algemene Kommissie moet geskied (NHKA 1914-1919:225-237).

Waar die kerkraad op 06 Julie 1917 dus besluit het om openlik die gesag van die Algemene Kommissie uit te daag, moes hulle op hierdie pad voortbeweeg toe ds. Van Broekhuizen reeds op 10 Julie die beroep aanvaar. Aangesien die bevestiging op 05 Augustus sou plaasvind, het die kerkraad op 04 Augustus 'n laaste buitengewone vergadering gehou. By hierdie vergadering het hulle kennis geneem van die korrespondensie tussen die skriba en di. Van Belkum en Brandt. Die laaste brief van die twee predikante (onderskeidelik skriba en voorsitter van die Algemene Kommissie) word 'als onbeduidend en zwak gekaraktiriseerd' (NHKA 1914-1919:243) geag - 'n laaste wanhopige poging om die bevestiging te stuit. Die kerkraad sal weereens die Algemene Kommissie inlig dat hulle hul houding diep betreur. Benewens die goedkeuring van al die toepaslike stukke in verband met die bevestiging, het die kerkraad ook 'n protes van twee lidmate teen die bevestiging ontvang. Dit is egter buite orde gereël (NHKA 1914-1919:241-245).

Ds. H.D. van Broekhuizen het derhalwe die onderskeiding dat hy in dieselfde stad twee gemeentes met dieselfde naam bedien het-behorende aan twee verskillende denominasies. Sy bevestiging het groot openbare belangstelling gaande gemaak. Selfs sy vorige gemeente het twee kerkraadslede afgevaardig om die geleentheid by te woon. In sy intreepreek het ds. Van Broekhuizen gemeld dat hy nie afskeid van sy vorige gemeente kon neem nie en dat hy vir byna 3 jaar glad nie meer die Woord kon verkondig nie (Du Toit 1982:212). 
Die feit dat die Kerkraad van Pretoria vir ds. Van Broekhuizen as leraar bevestig het, sou uiteraard die belangstelling in die buitengewone Algemene Kerkvergadering vergroot. Hierdie vergadering wat uiteindelik op 20, 21 en 22 November 1917 plaasgevind het, kan met reg as die 'Van Broekhuizen - Algemene Kerkvergadering' beskryf word. Uit die bespreking het dit geblyk dat daar selfs 'n dreigende skeuring in die NHKA oor hierdie aangeleentheid was.

Voordat die vergadering van die Algemene Kommissie plaasgevind het, het twee besondere brosjures verskyn: een van die kerkraad (soos besluit op 06 Julie 1917) asook een deur die Algemene Kommissie. Die brosjure van die kerkraad lui heel gepas:

Het Geschil van de Kommissie der Algemene Kerkvergadering van de Nederd. Herv. Kerk van Zuid-Afrika, met de Kerkeraad van Pretoria in zake de Beroeping van ds. Herman D. Van Broekhuizen. (NHKA 1917a)

Die ander brosjure se naam is: 'Uiteenzetting van het Standpunt van de Commissie der Algemeene Kerkvergadering naar aanleiding van de Brochure van de Kerkeraad van Pretoria over de jongste Beroeping aldaar' (NHKA 1917b).

In die voorwoord verwys die kerkraad na die onverkwiklike stryd wat tussen die Algemene Kommissie en die Kerkraad ontstaan het. Kerkrade word dan versoek om die brosjure (34 bladsye) te bestudeer sodat hulle afgevaardigdes op die Algemene Vergadering goed ingelig is. Dit blyk uit die uiteensetting dat die skriba van die beroepsvergadering nie die beroepsbrief (soos vereis) aan die beroepene gestuur het nie, maar met die skriba van die Algemene Kommissie geskakel het. Dit het daartoe gelei dat die Algemene Kommissie standpunt ingeneem het. Die betrokke skriba het nie tydens die beroepsvergadering enige blyke gegee dat hy nie genoeë neem met die beroep wat uitgebring is nie. Die betrokke skriba het homself later verweer deur te verklaar dat hy ds. Van Belkum nie as skriba gekontak het nie, maar in sy privaat hoedanigheid. 'Nu, wat dat ekskuus waard is, kan ieder voor zichzelf uitmaken ... De gevoerde korrespondentie is echter de Kerkeraad onthouden' (NHKA 1917a:4). 'n Deeglike uiteensetting van Artikel 57 word gegee waarin die kerkraad die oortuiging uitspreek dat die betrokke artikel slegs slaan op proponente en nie op reeds bevestigde leraars van 'n susterskerk nie (NHKA 1917a:7). Die volledige relaas word dan van die geskiedenis sedert die beroepingsvergadering gegee.

Die Algemene Kommissie se brosjure bevat hulle volledige antwoord in 16 bladsye. Die inluidende paragraaf gee 'n duidelik uiteensetting van hulle standpunt:

Het is zeker niet noodig te constateeren, dat de vraag, waarom het gaat, niet is of Ds. H. D. van Broekhuizen predikant zal zijn van de Nederduitsch Hervormde Gemeente van Pretoria, maar of er in de toekomst een Nederduitsch Hervormde Kerk in Zuid Afrika zal bestaan of niet. Daarom heeft de Algemeene Commissie niet de verantwoordelijkheid op zich te willen nemen in deze zaak, doch een buitengewone Algemeene Kerkvergadering samengeroepen om in dezen te beslissen. (NHKA 1917b:3)
Daar moet oor twee sake duidelikheid verkry word. Die eerste is of die uitleg van die Kerkwet korrek is of nie. Die tweede word as volg verwoord:

... ten tweede, of wij langer zullen toelaten, dat predikanten van andere kerkgenootschappen kunnen beroepen worden in onze kerk, zonder dat zij naar onze kerk zijn overgekomen en beroepbaar verklaard zijn in onze kerk en zonder dat zij door woord of daad hebben getoond, tot de Nederduitsch Hervormde kerk te behooren. (NHKA 1917b:3)

Hierna volg dan 'n breedvoerige bespreking van hulle vertolking van die kerkwet asook die feit dat daar pas met eie teologiese opleiding ' $n$ aanvang geneem is. Hulle beweer verder dat die verklaring wat ds. Van Broekhuizen gegee het aan die skriba van die Kerkraad gerig is en nie aan die Algemene Kommissie nie (NHKA 1917b:12).

Die feit van eie teologiese opleiding tel baie vir die Kommissie. Die feit is dat gemeentes betaal vir die opleiding, en dus kan sekerlik verwag word dat daar gemeentes sal wees waarin hierdie opgeleides sal dien en 'dat niet alle vacatures zullen opgevuld worden met vreemdelingen, voordat zij klaar zijn met hun studie' (NHKA 1917b:13).

Laastens word die Pretoria-gemeente voor stok gekry omdat hulle met hulle vorige beroep (van dr. Greyvenstein) vyf keer predikante van die Verenigde Kerk (NGK) beroep het, waarvan vier bedank het. Die vraag word dan gevra of die Pretoria-gemeente hulle nie steur aan die geskiedenis van die kerk, aan die besluite van die Algemene Vergadering en aan die beginsel van eie opleiding nie? 'Wat voor aanmoediging is dit voor jonge studenten, als zij zien, dat de voornaamste gemeente in de hoofdstad van Transvaal voortgaat uit de Verenigde kerk te beroepen?' (NHKA 1917b:13).

Die tafel was dus voorberei vir 'n hewige bespreking op die Algemene Vergadering.

Die eerste saak waaroor duidelikheid gekry moes word, was die vertolking van Artikel 57 van die Kerkwet. Uiteindelik word die Algemene Kommissie met 63 stemme teen 17 gelyk gegee in hul vertolking - Pretoria moes eers toestemming verkry het voordat hulle kon beroep (NHKA 1909-1922 [A 1/8, 1917:355-360]; De Hervormer, 15.12.1917:5-6).

Gedurende die bespreking wys ds. J.J. Kuhn daarop dat dit verkeerd is dat "vette posten" gegeven worden aan predikanten uit andere kerken', terwyl die predikante in die NHKA wat hard gewerk het, verbygegaan is (NHKA 1909-1922 [1917:12]). Ds. Van Belkum wys weer daarop dat die Pretoria-gemeente nog altyd voorkeur gegee het daaraan om iemand uit die Verenigde (NG) Kerk te beroep (NHKA 1909-1922 [1917:20]). Ander het geargumenteer dat dr. Greyvenstein, wat die jongmanne moet oplei, 'n groter gevaar sou inhou as ds. Van Broekhuizen, en tog reken die spreker dat daar geen sodanige gevaar bestaan nie (NHKA 1909-1922 [1917:19]). 
Die res van die bespreking het verder oor die meriete van Pretoria se saak gehandel. Een leraar meen dat die kerkraad ds. Van Broekhuizen beroep het vanweë die verwagting dat 300 lidmate saam met hom vanuit die NGK sou oorkom. Die bespreking was so uitgerek dat besluit is om ' $n$ valbylreël in te stel, naamlik vir 16 h00 op 22 November. Net twee voorstelle het toe gedien: een dat ds. Van Broekhuizen herbevestig moet word en die ander dat die bevestiging goedgekeur word ten spyte van die feit dat die kerkraad gefouteer het. Laasgenoemde voorstel is met 43 stemme teenoor 32 aanvaar. Hierop is ds. Van Broekhuizen hartlik in die vergadering verwelkom (NHKA 1909-1922 [1917:378-383]).

Van Broekhuizen word so byna by die volgende vergadering (1919) as onder-voorsitter van die vergadering verkies! (NHKA 1909-1922 [1919:48]).

Dit is redelik duidelik uit die verdere verloop van sake dat die beroep van Van Broekhuizen iets van 'n afsluitingsperiode vir beroepe van NGK predikante na NHKA gemeentes was. In die periode tot 1934 kon slegs een ander beroep opgespoor word en dit was uitgebring deur die kombinasie Ventersdorp, Lichtenburg en Makwassie wat vir prop. P.J. Ebersohn (NG Kerk) beroep het (De Hervormer, 15.2.1918:8; 15.4.1918:8; Anoniem 1934:236).

\section{Slot}

Aangesien die opset van hierdie artikel 1917 as die tegniese afsnypunt beskou het (toe daar met die eie teologiese opleiding begin is), is die oor-en-weer beroepe daarna nie nagevolg nie. Dit is verder positief om te kon verneem dat die twee kerke in 2014 'n Memorandum van Ooreenkoms aangegaan het. In paragraaf 3.6 van hierdie Memorandum van Ooreenkoms word verklaar dat predikante van een kerk na die ander beroep mag word kragtens elke kerk se kerkordelike reëlings (Die Nederduitse Gereformeerde Kerk [NGK] 2015:Bylaag 2).

\section{Erkenning Mededingende belange}

Die outeur verklaar dat hy geen finansiële of persoonlike verhouding(s) het wat hom op 'n voordelige of nadelige wyse in die skryf van die artikel beïnvloed het nie.

\section{Literatuurverwysings}

Anoniem, 1934, Gedenkboek van die Teol. Seminarie (N.G. Kerk) Stellenbosch, Driekwart Eeufees 1859-1934, Pro Ecclesia, Stellenbosch.

De Hervormer, 15.3.1917; 15.7.1917; 15.12.1917; 15.2.1918; 15.4.1918

Du Toit, F.G.M., 1979, Hermanus Stephanus Bosman 1848-1933, NG Kerk Boekhandel, Pretoria.

Du Toit, P.R., 1982, 'Die drie Afrikaanse kerke en die Rebellie', DD-proefskrif, Dept. Kerkgeskiedenis en Kerkreg, Universiteit van Pretoria.

Engelbrecht, S.P., 1953, Geskiedenis van die Nederduitsch Hervormde Kerk van Afrika, 3de uitg., HAUM, Kaapstad.

Gerdener, G.B.A., 1930, Boustowwe vir die Geskiedenis van die NederduitsGereformeerde Kerk in die Transgariep, Nasionale Pers, Kaapstad.

Keet, D.J. (red.), 1942, Wonderdade van God: Jubileum Gedenkboek van die Ned. Herv. of Geref. Kerk van Suid-Afrika 1842-1942, Voortrekkerpers, Johannesburg.

Nederduitse Gereformeerde Kerk (NGK), 2015, Memorandum van ooreenkoms aangegaan tussen die Nederduitsch Hervormde Kerk van Afrika en die Nederduitse Gereformeerde Kerk, Bylaag 2, Agenda, Die Nederduitse Gereformeerde Kerk, Moderamen (2013-2015), Vyfde Vergadering, 23-25 Februarie 2015.

Nederduitsch Hervormde Kerk van Afrika (NHKA), 1909-1922, Notule van die Algemene Kerkvergadering, K1/1 1903-1922, Kerkargief, Pretoria.

Nederduitsch Hervormde Kerk van Afrika (NHKA), 1914-1919, Notule van die Kerkraad, Pretoria, G4/8 1/2/5, Kerkargief, Pretoria.

Nederduitsch Hervormde Kerk van Afrika (NHKA), 1917a, Het Gesschil van de Kommissie der Algemene Kerkvergadering van de Nederd. Herv. Kerk van Zuid-Afrika met de Kerkeraad van Pretoria, in zake de Beroeping van Ds. Herman D. van Broekhuizen, Brosjure genommer 109, Noordelike Drukpers, Pretoria.

Nederduitsch Hervormde Kerk van Afrika (NHKA), 1917b, Notule van die Kommissie van die Algemene Kerkvergadering, B1/2. 18.4.1917, 20.06.1917, Kerkargief, Pretoria

Nederduitsch Hervormde Kerk van Afrika (NHKA), 1917c, 1917, Uiteenzetting van het Standpunt van de Commissie de Algemeene Kerkvergadering naar aanleiding van de Brochure van den Kerkeraad van Pretoria over de Jongste Beroeping Aldaar, Brosjure genommer 85 .

Rex, H.M., 1968, 'In memoriam: Prof. Dr. J.H.J.A. Greyvenstein', Die Hervormer, Januarie, bl. 21-24.

Scholtz, G.D., 1956, Die Geskiedenis van die Nederduitse Hervormde of Gereformeerde Kerk van Suid-Afrika, 1842-1885, NG Kerk Uitgewers, Kaapstad, Pretoria.

Scholtz, G.D., 1960, Die Geskiedenis van die Nederduitse Hervormde of Gereformeerde Kerk van Suid-Afrika, 1885-1910, NG Kerk Uitgewers, Kaapstad, Pretoria. 